\title{
The Teton Dam Failure as a Support of an Undergraduate Course of SoIl Mechanics
}

\author{
Benoît Courcelles \\ Polytechnique Montréal \\ benoit.courcelles@polymtl.ca
}

\begin{abstract}
To improve the attractiveness of the undergraduate course of Soil Mechanics at Polytechnique Montreal, a new approach relying on the study of the Teton Dam failure from a forensic point of view was introduced in 2012. A course evaluation performed at the end of the session demonstrated that the case study was very interesting to sensitize the students to technical and non-technical aspects, but that the formula was not ideal for active learning. Indeed, the lack of hindsight was not adequate to warranty an active participation of all students. As a consequence, a new version of the case study based on team projects is under development.

The paper presents the new case study approach, the methodology and the tools under development to help the students with the case study and finally concludes with the implication of the case study in the formation of future engineers.
\end{abstract}

Keywords: Case study, undergraduate course, soil mechanics, team work, failure.

\section{INTRODUCTION}

The motivation of the paper is to address two issues following the increasing of civil engineering students during the last decade:

- Considering their large number, it is difficult to maintain a close relationship between the professor and the students. Indeed, a total of 300 students took this course during the academic year of 2012-2013.

- Their interest to the different fields of activities in civil engineering is variable and, as the course of soil mechanics arrives later in their curriculum, the attraction of geotechnical engineering is sometimes limited. Indeed, this introductory course is placed in the third year of the curriculum for some reasons of prerequisites and most of the students have already chosen another field of interest such as infrastructure, transport, civil engineering materials ...
As a consequence of these observations, the aim of the present paper is to develop a teaching approach able (1) to catch the interest of a large number of students and (2) to reinforce the attraction of geotechnical engineering. To this end, we decided to introduce a case study as a support of active learning.

A case study presents some benefits as an interactive learning strategy, shifting the emphasis from teachercentered to more student-centered activities [1]. It also facilitates the interaction with peers and contributes to the development of skills such as capacity to analyze and synthetize [2]. Moreover, the use of case studies encourages the development of critical thinking and helps the students to make meaningful connections between their prior knowledge and the case materials [3]. Finally, case studies connect students to real life problem, which will help them in their future decisions as a professional [4].

As regards its format, a case study is the representation of real-life or life-like situations [5]. It can contain multiple resources and includes a sufficient level of detail for the learning and teaching purpose [5], but it should not be too complex with respect to the level of the students. This last point represents a fundamental problem to implement a case study in our course of soil mechanics. Indeed, this course constitutes an introduction to this field of engineering and the students do not have a sufficient background to deal with complex studies.

Considering the difficulty to adapt the case study to the audience, the paper will present the evolution of the case study used in the course of soil mechanics at Polytechnique Montreal. Thus, the main contribution of this paper is to present the adaptation of the case study as a result of a formal evaluation performed by the students.

\section{EVOLUTION OF THE CASE STUDY}

\subsection{First implementation of the case study}

To improve the attraction of the course, a grant was obtained in 2012 from the Center for teaching and learning in Polytechnique Montreal. This grant has been 
dedicated to the redevelopment of the course material and the introduction of case studies, including:

- a collection of exercises based on real geotechnical problems to be used in small classes ( $<25$ students). Used since the fall 2012 semester, this collection of exercises has enabled the teachers to catch students' attention and has limited the time dedicated to the resolution of exercises thanks to detailed answer keys.

- a case study based on the Teton Dam failure in 1976, which was presented during the lectures. The two objectives of this case study were to raise the attractiveness of the course and to allow a direct link between theory and practice. Throughout the session, references to the Teton Dam were performed at the end of each lecture as an immediate application of the theory. Several themes were treated along the semester, such as selection of soils, compaction, groundwater flow, total and effective stresses and, of course, the failure of the dam.

References to the case were done at the end of lectures, during a 10 to $15 \mathrm{~min}$ presentation. A reference to the case study represents the illustration of each main chapter in the planning. The scheme of each reference to the case study was as follows [6]:

- Brief links to the lecture to highlight the main points of the course,

- Presentation of a particular element related to the case study: particular design, choice of materials, geology, hydraulic...

- Question related to this element, such as "why a particular design has been retained? What is the impact of the geology on the project? Could we have chosen other materials for the construction of the project?"

- Reflection in small groups (3 to 4 people)

- Answers and synthesis with whole classroom.

The choice of this case study was guided by the learning objectives of the course: the case of the Teton Dam is large enough to encompass all the concepts covered during the semester without being too complex. The case study was implemented for the first time in the fall 2012 and a specific questionnaire within the teaching evaluation has been filled up by the students at the end of the semester. This survey has demonstrated the appreciation of this approach, as $94 \%$ of the respondents found the case study appropriate to the course of soil mechanics and $85 \%$ considered the Teton Dam as really interesting. However, several relevant suggestions were made through the questionnaire [7]:

- $90 \%$ of respondents thought that the questions asked during each presentation of the case study should have been given in advance to prepare the students to new concepts, and $74 \%$ suggested to read the evaluations of experts performed during post-failure investigations,
- $87 \%$ suggested adding exercises and team-works based on the Teton Dam,

- $83 \%$ indicated that ethical aspects could have been more developed, although $80 \%$ of them agreed that the Teton Dam allowed to better understand the extent of the responsibilities of engineers, and finally,

- $69 \%$ would rather to focus on other non-technical aspects such as project economics, management, human relationships...

These comments highlighted new pedagogic problems, which motivated the evolution of the case study:

- the students were not prepared adequately before each presentation of the case, resulting in some difficulties to promote active learning;

- the limitation of the case study to Powerpoint presentations and few questions in connection with the lecture limited the involvement of students;

- ethical, economic and human aspects were discussed in the case study, but a deepening is needed to really sensitize students to the management of engineering projects.

\subsection{New approach for the case study}

As a consequence of the previous pedagogic problems, the case study has been reviewed to enhance the attractiveness of the soil mechanics course, but also to sensitize the students to some of the 12 qualities identified by the Canadian Engineering Accreditation Board (CEAB). Indeed, the soil mechanics course currently allows the students to develop basic qualities, such as scientific knowledge or ability to analyze problems and to conduct investigations through laboratory works. In addition, the case study, as presented in the Fall 2012, allowed them to grasp some aspects of professionalism.

To address other qualities identified by the CEAB and to respond to students' suggestions, team works are being incorporated in the case study. These team works aim to provide a new design of a part of the Teton Dam and to develop their performances in communication through public presentations at the end of the semester. In addition, the team works allow a thorough study of project management thanks to the introduction of constraints relative to environmental, ethical and economic aspects.

To reinforce the relationship between the students and the teachers, this team works will be initiated in small classes ( $<25$ students) divided in teams of 4 people. The final presentations of team works will be performed in a plenary session involving all teams.

Given the limited knowledge of the students after the course, the new design can't address the entire dam, but may however introduce analysis methods to prepare the subsequent course of foundations, mainly based on engineering design. 


\section{RESULTS AND DISCUSSION}

\subsection{New material of the case study}

Usually, indications of the resources that may be required in the case study should be provided to the students [5]. These resources include, but are not limited to:

- Materials needed during the task, such as access to specific software or charts;

- Materials needed to present their results such as worksheets or report templates;

- References such as a chapter of a textbook or a journal article.

Moreover, it is important to give clear instructions about what the students are required to do with this case material [5]. Thus, an open-ended question reinforces problem-based learning, encourages students to be actively involved, cooperate with peers and receive feedback [8], and also provides an opportunity to practice "soft skills" such as interpersonal and teamworking skills [8]. In addition, it is useful to give an indication of the length of each task asked to the students [5].

To meet these requirements, the following additions are being performed to the case study: (1) a synthesis of experts' investigations performed after the failure of the dam, and (2) several team works related to the design of a part of a "new" Teton Dam.

The synthesis of experts' investigations performed after the failure of the dam will enable students to be better prepared to the new matter presented in class and will reinforce the importance of investigations without limiting them to a summary presented in the classroom. Recommended readings before each lecture should also tend to substantially improve the participation of the students. To be sure that the synthesis will be adapted to undergraduate students, former students and new graduate students are involved in the preparation of the document. This team works under the supervision of the professor to insure a quality assurance of the results.

As regards the post-failure investigations, two groups of independent experts conducted investigations after the disaster: the "Independent Panel" and the "Interior Review Group". In addition, many studies have been conducted retrospectively and numerous articles have reported this case. Given the limited skills of students in geotechnical engineering at this stage of their formation, it is necessary to retain relevant information and provide guidance in reading studies expertise. As a consequence, four themes have been retained for the synthesis: soil classification, compaction, permeability, and shear strength. For instance, the first theme will include all features of Loess implemented in the core of the dam (particle size, Atterberg limits, relative density of grains, compactibility...), and will comprise a thorough analysis and explanation of contradictory opinions.

On the other hand, the team works related to the design of a part of a "new" Teton Dam will be based on the synthesis of experts' opinions. Such works will allow the students to take advantage of mistakes made in the design of the Teton Dam, which will strengthen the interaction between theory and practice. In addition, a special attention will be paid to the integration of economic, environmental and human aspects of the work, which will promote the development of project management.

Table 1: Teaching program and case study

\begin{tabular}{|c|c|c|}
\hline $\begin{array}{c}\text { Theme of the } \\
\text { lecture }\end{array}$ & Case study & Team-works \\
\hline $\begin{array}{l}\text { Description and } \\
\text { classification of } \\
\text { soils (I) }\end{array}$ & $\begin{array}{l}\text { - } \begin{array}{l}\text { Presentation of the } \\
\text { Teton } \\
\text { localisation, geology, } \\
\text { failure... }\end{array} \\
\end{array}$ & \multirow{5}{*}{$\begin{array}{c}\text { Work 1: Selection } \\
\text { and implementation } \\
\text { of a new core } \\
\text { material. }\end{array}$} \\
\hline $\begin{array}{l}\text { Description and } \\
\text { classification of } \\
\text { soils (II). }\end{array}$ & $\begin{array}{l}\text { - Classification of the } \\
\text { dam's materials: core, } \\
\text { faces, } \\
\text { - Problem of Loess } \\
\text { chosen for the core, } \\
\text { - Atterberg's limits for } \\
\text { the core }\end{array}$ & \\
\hline $\begin{array}{l}\text { Description and } \\
\text { classification of } \\
\text { soils (III) }\end{array}$ & $\begin{array}{l}\text { - Optimum Proctor } \\
\text { curves used for the } \\
\text { design of the dam. } \\
\text { - Method } \\
\begin{array}{l}\text { compaction of the } \\
\text { core. }\end{array}\end{array}$ & \\
\hline Stresses in soils & $\begin{array}{l}\text { - Influence of water on } \\
\text { the mechanical } \\
\text { behavior of Loess. }\end{array}$ & \\
\hline Water in soils (I) & - Stresses in the core. & \\
\hline Water in soils (II) & $\begin{array}{l}\text { - Treatment of the } \\
\text { dam's foundation } \\
\text { (waterproofing) }\end{array}$ & \multirow{6}{*}{$\begin{array}{l}\text { Work 2: New design } \\
\text { for the injections } \\
\text { under the dam. }\end{array}$} \\
\hline Water in soils (III) & $\begin{array}{l}\text { - Flow net in a section } \\
\text { of the dam. Drainage. }\end{array}$ & \\
\hline $\begin{array}{l}\text { Consolidation and } \\
\text { settlement. Rate of } \\
\text { consolidation. }\end{array}$ & $\begin{array}{l}\text { - Effect of first filling } \\
\text { up on the deformation } \\
\text { of the dam. }\end{array}$ & \\
\hline $\begin{array}{l}\text { Mohr's circles and } \\
\text { theory of rupture. }\end{array}$ & $\begin{array}{l}\text { - Dam's behavior in } \\
\text { case of quick } \\
\text { drawdown. }\end{array}$ & \\
\hline $\begin{array}{c}\text { Shear strength of } \\
\text { non-cohesive and } \\
\text { cohesive soils. } \\
\end{array}$ & $\begin{array}{l}\text { - Slope stability (dam } \\
\text { and canyon located } \\
\text { upstream). }\end{array}$ & \\
\hline $\begin{array}{l}\text { Synthesis: key } \\
\text { elements }\end{array}$ & - Case synthesis & \\
\hline
\end{tabular}

The starting point of team works will be the mistakes encountered in the design or construction works, including:

- improper choice of Loess for the core, since it was mainly guided by economic considerations and not by their mechanical performances. This material has indeed a very low plasticity index, which induces a significant 
modification of behavior with a relatively low change in their water content;

- imperfections in the sealing under the dam, which allowed the passage of groundwater and the erosion of materials.

For completion of the team works, it is planned to set up a document containing:

- a bank of materials used for the construction of a new dam, including their mechanical, hydraulic and economic (material costs, suppliers, distances...)

- a detailed geological section of the sector, including permeability and fracturing tests,

- a collection of technical characteristics of equipment for compaction and injection.

These elements will be used to realize two team works: the first will be related to the selection of a new material for the dam and its implementation (compaction), and the second will deal with the design of soil injections under the dam. The position of the team works during the semester, as well as the presentation of the case study in class are presented in Table 1. Following this works, the students will have acquired the methodology to perform a design, which will be enhanced in the subsequent course of foundations.

\section{CONCLUSION}

The introduction of a case study in the course of soil mechanics in the Fall 2012 succeeded in improving its attractiveness, but pointed out several potential improvements, such as a better preparation of the students before the presentation of the case study. Thus, the introduction of team works and the realization of a synthesis of experts' opinions are expected to address students' observations with respect to the first version of the case study.

Moreover, the involvement of former students and graduate students in the preparation of the material insures the adequacy between the background of the students and the complexity of the case. Finally, the team works are expected to sensitize the students to project management and to provide an opportunity for the development of transferable skills such as communication, team-work, analysis, synthesis, and time management.

\section{Acknowledgements}

The Center for teaching and learning in Polytechnique Montreal is acknowledged its financial support for developing the two version of the Teton Dam case study.

\section{References}

[1] Grant, R., "A claim for the case method in the teaching of geography", Journal of Geography in Higher Education, vol. 21, no. 2, pp171-185, 1997.

[2] Duncan, M. J., Lyons, M. \& Al-Nakeeb, Y., "You have to do it rather than being in a class and just listening: the impact of problem-based learning on the student experience in sports and exercise biomechanics", Journal of Hospitality, Leisure, Sport and Tourism Education, 6(1), pp. 71-80, 2007.

[3] Martin, L., West, J. \& Bill, K., "Incorporating Problembased Learning Strategies to Develop Learner Autonomy and Employability Skills in Sports Science Undergraduates", Journal of Hospitality, Leisure, Sport \& Tourism Education, 7(1), pp. 4-17, 2008.

[4] Breslin, M. \& Buchanan, R., "On the Case Study Method of Research and Teaching in Design", Design Issues, 24(1), pp. 36-40, 2008.

[5] Cox, S., Case Studies for Active Learning, Learning and teaching guides, Hospitality, Leisure, Sport and Tourism Network, 2009.

[6] Courcelles, B., Forest, L., Kozanitis, A., Students as forensic engineers: An innovative approach to teaching Soil Mechanics, in Proc. $7^{\text {th }}$ International Conference on Case Histories in Geotechnical Engineering, 29 April-4 May, Chicago, IL, USA, 2013.

[7] Courcelles, B., Forest, L., Kozanitis, A., The use of case studies to teaching Soil Mechanics, in Proc. Canadian Society for Civil Engineering, Annual conference, 29 May 1 June, Montreal, Quebec, Canada, 2013.

[8] Duncan, M. J. \& Al-Nakeeb, Y., "Using Problem-based Learning in Sports Related Courses: An Overview of Module Development and Student Responses in an Undergraduate Sports Studies Module", Journal of Hospitality, Leisure, Sport and Tourism Education, 5(1), pp. 50-57, 2006. 